\title{
On Transition from the Second Industrial Revolution to the Fourth one
}

\author{
Oleg N. Yanitsky \\ Prof., Dr. of Sciences (Philosophy), Chief Researcher, the Federal Research Sociological Center of \\ Russian academy of sciences
}

\begin{abstract}
The article examines main shifts in global situation in the period of 1960-2000s years through the lenses of transition from the Second industrial revolution to the Fourth one. An underlying idea of the study is to trace the shifts in all substantial spheres of human activity ranging from mode of production and consumption to the means of peaceful and armed struggle between national and global stakeholders for resources and geopolitical domination. I realize that such approach is rather schematic and partial but I see necessary to sketch an overall picture of global trends during the above period and to compare their mutual interdependence. Given analysis confirms the viewpoint of those leading global researchers who state that the ongoing changes have an all-embracing and all-penetrating character. That is the technological innovations and integrative socio-technological systems exert an impact on all spheres of life of humanity, including their tempo-rhythms. At the same time, in spite of the above changes humanity continues to behave as a biological species. In order to embrace these multi-sided transformations the humanitarians, media designers and journalists should to maintain problem-oriented and interdisciplinary approaches. The article concludes that the emergence of virtual society generated by the Fourth industrial revolution is Janus like: it simultaneously provides both the unique opportunities for humans and deadly threats. The further the more modern society will be governed by media-constructed information flows.
\end{abstract}

Keywords: Globalization, Dynamics, Geopolitics, Humanity, Knowledge, Means of Production, Media, Technology, the SBT-Systems, Values

\section{INTRODUCTION}

During the time span from early 1960s to late 2010s the all-embracing shifts in the structure and functioning of global community have passed. These sifts have two adversarial interpretations. A technocratic-oriented thought inclined to interpret them as the results of transition from the Second (i.e. industrial) to the Fourth (i.e. information-communication) revolutions. A humanistic-oriented thought usually explains these shifts by the transition from material to post-material values. It is indicative that each of these adversarial camps usually practice mono-disciplinary mode of thinking. Except some researchers like U. Beck (1999, 2007, 2010, 2015), A. Giddens (1992, 2009), D. Meadows (1973, 1989), G. Myrdal (1968), A. Touraine et. al. (1983), J. Urry (2008, 2011) there were no serious attempts to interpret ongoing globalization process as complex socio-bio-technical phenomenon with its own logic of functioning and development. It has been a well-understandable phenomenon. On the one hand, from the times of the Enlightenment onwards the humanities continued to separate each other building the institutional barriers between them. In particular, it refers to the sociology which strived to be institutionalized and publicly accepted. On the other hand, the 'modern' humanities and media designers remained under influence of natural sciences that have not only a long-term history but have been socially and politically accepted. From the viewpoint of national and global stakeholders, the domination of the latter trend is well-understandable: natural sciences have been the main driver of any kind of industry and the institution which maintain national security whereas the humanities remain a 'berry on the cake.'

The process of merging of natural and technical sciences has begun in the medicine and agrobiology and agro-technics in early 1960s since these disciplines have been of a paramount importance from the viewpoint of national health, security and wellbeing. Nevertheless, it is surprising because such globally-known humanitarians as B. Commoner, I. Goffman, T. Parsons and his follower prof. R. Fox have initially been the doctors or the biologists. And wise versa, but why? My explanation of these 
facts is in a phenomenon of civil-oriented scientists. For example, world-known Russian geochemist V. Vernadsky, the author of the Biosphere concept, had simultaneously been a politician at two levels, as a member of a local self-government (zemstwo) and a state-level professional politician. The same may be said about P. Sorokin, an American sociologist of Russian origin whose early work had been called 'A Hunger as a Factor...' (English version 'A Man in Calamity').

Radical turn toward a domination of tandem of natural and technical sciences had happened in between the WWI and the WWII. It had become clear that modern technologies including military ones are mighty force in the struggle of the states and their alliances for new resource sources and geopolitical domination. But it would be a mistake to reduce all ongoing transformations and challenges to the impact of the Fourth technological revolution. To my mind, this revolution is only the label of a couple of interrelated shifts such as: (1) value system transformations; (2) changes in character and time speed (tempo-rhythms) of global order; (3) shifts in man-nature relationships; (4) in relations between transnationals, nation-states and civil society organizations; (5) in relationships between labor, education and service structures; (6) in development of information-communication (IC) sphere and social media; (7) in the type of personality (individual) and its primary eco-structure; and (8) in the institute of knowledge production and dissemination.

There is no sense to look for who are the leader and the follower among them. Recent phase of globalization is a highly complex and interdependent phenomenon. Nevertheless, initially the main transformation impulses have been produced by the global stakeholders seeking for new sources of capital accumulation and means of geopolitical domination. It is they who generated the developments in all abovementioned realms of global life. To my mind, a technocratic ideology coupled with media-constructed information flow has become dominating forces.

It, in turn, leads to gradual transformation of the Biosphere into the sociobiotechnosphere (hereafter the SBT-system), that is in a certain wholeness which has its own regularities of 'behavior' (Yanitsky, 2016). This global SBT-system may be called as geosphere, anthroposphere, etc. The coming global warming is one of its feedbacks which mechanisms are still not clear.

Therefore, the aim of this article is not to decompose global SBT-system into elements but to try to understand how its relatively independent parts are interacting within this global whole. The following analysis of characteristics of these parts and their transformations is needed for formulating the hypotheses of their role in changes in global whole and its impact on human community in a set of coming decades.

\section{Coming of TeChNOCRATIC IDEOLOGY}

In the first period under consideration the ideology of sustainable development has been dominated. It appears that the 'developing countries' are capable to catch up the developed ones with assistance of international organizations (Bruntland and Khalid 1987). It was a period of spatial spread of ideology of development by means of the use of new resources. Speaking in the terms of natural sciences, it was a period of relatively 'calm sun.' In social politics dominated the ideas of educational and cultural development, in geopolitics - the ideas of lowering international tension and more mutual trust. It is during this period the principle of the limits of growth has been moved forth and substantiated in the series of reports to the Roma Club. Some of theorists spoke in favor of meritocracy ideology. Finally, whereas in the first period there was an open request for reconsideration of basic values with the accent on importance of non-material values (Meadows et al., 1973; Rozzak, 1973; Toffler, 1970) nowadays a consumer ideology took over in a global scale.

In the second period the coming of the Fourth technological revolution has been accompanied by a rapid growth of new technologies and accordingly by the spread of technocratic ideology. Unfortunately, there were quite a few attempts to comprehend this turn sociologically (Sassen, 2002; Schwab, 2016). Being originated from technological innovations, technocratic ideology has not been restricted by the sphere of material production but exerted its impact on all spheres of human life. The ideology of sustainable development has been replaced by idea of unlimited consumption growth, the principle of lowering of international tensions - by its rapid growth, protection of natural and cultural diversity - by forced unification of consumers' demands, etc. Anglo-Saxon sociologists and politicians show concern about growing poverty and social inequality but decisive steps to overcome these gaps has not been taken yet. More than that, the technocrats predict that the IC-technologies continue to replace the 'Internet of people' by the 'Internet of things'. 
Table1. Value system transformations

\begin{tabular}{|l|l|l|}
\hline & $1960-1980$ s & 2000 and onwards \\
\hline $\begin{array}{l}\text { Leading trend } \\
\text { Its basic driving force }\end{array}$ & $\begin{array}{l}\text { Mainly sustainable development } \\
\text { Growth of educational, cultural and other } \\
\text { non-material needs } \\
\text { Lnternational } \\
\text { relationships }\end{array}$ & $\begin{array}{l}\text { Consumption growth } \\
\text { Permanent growth of consumer } \\
\text { demand }\end{array}$ \\
$\begin{array}{l}\text { Role of new } \\
\text { technologies in it } \\
\text { Man and the Biosphere } \\
\text { relationships }\end{array}$ & $\begin{array}{l}\text { Growth of mutual understanding and } \\
\text { protection of local diversity } \\
\text { Ideology of limits of growth and modest } \\
\text { demands }\end{array}$ & $\begin{array}{l}\text { Forstrust } \\
\text { Forced unification of global values } \\
\text { and their carriers } \\
\text { Accelerating transformation of the } \\
\text { Biosphere into global socio } \\
\text { biotechnical system }\end{array}$ \\
\hline
\end{tabular}

\section{Changing Character of Global Dynamics}

Its main features are as following: a decisive turn from the idea of sustainable development to a geopolitical constructivism, acceleration of the run of events, and the emergence of a lot of technologically-constructed systems which are needed in permanent monitoring and maintenance. The further the more the transnationals took over the nation-states. It means the end of bipolar (balanced) world and the emergence of multipolar one which is very mobile and unpredictable. This world is much more unstable with nonlinear type of global dynamics accompanied with unintended consequences and bifurcations. Anglo-Saxon stakeholders armed with IC-technologies and allembracing mass-media institute accelerate their invasion into less-developed countries, often establishing in them social order named as a 'governed chaos.' A new turn of struggle for various resources and geopolitical domination has begun. The idea of gradual convergence of two systems (capitalist and socialist ones) has been thrown away. Territorially-based global dynamics has been replaced by network-structured one. This fact signifies an acceleration of the tempo-rhythms of global dynamics. This dynamics is accompanied with social and political instability and the degradation of vast natural ecosystems and already built-in areas (large cities, towns, local communities). An idea of thrifty use of natural resources is only proclaimed but not seriously implemented. In sum, accelerating transformation of the Biosphere into global sociobiotechnical system with unpredictable consequences is going on. The Asian Energy Ring project aimed for driving an economic growth of the region and cooperation among the countries is the best example (Shvartz and Simonov 2015). Table2. Changing character of global dynamics

\begin{tabular}{|c|c|c|}
\hline & 1960-1980s & 2000 and onwards \\
\hline Leading trend & Sustainable development & Geopolitical constructivism \\
\hline Its driving force & Nation-states and their alliances & Transnationals \\
\hline Type of global dynamics & Relatively linear & Non-linear with bifurcations \\
\hline Structure of this dynamics & Territorially-structured & Network-structured \\
\hline Role of IC-technologies & & \\
\hline Leading geopolitical & Humanity goods & Instrument of global leadership \\
\hline principle & Convergence, mutual understanding & Geopolitical domination, 'governed \\
\hline Role of the Biosphere & An endless source of resources & chaos' \\
\hline Major instruments & Economic growth & $\begin{array}{l}\text { The force changing global social order } \\
\text { Economic and political ties are } \\
\text { permanently switching }\end{array}$ \\
\hline
\end{tabular}

\section{Shifts in Global Social ORder}

In the first period, the techno-bureaucrats, civilian and military, have been the key actors in a majority of the developing countries (Guimarães, 1991). In the western world, the domination of liberal ideology of 1960-80s has been gradually replaced by technocratic one often with a right turn. Liberal and technocratic ideologies are hard to combine because actual technocratism is usually accompanied with various kinds of forced politics. Then, liberal democracy is hard to maintain under conditions of multi-polar world. The further the more the liberal democracy of Anglo-Saxon world is associated with colored revolutions, hackers' attacks and hybrid wars across the world. Accordingly, the role of the UN and other international organizations aimed at the maintenance of peace and democracy is going down. It means that the world is returning back, to the times of mutual threats, political pressure and local wars. Peace movement has disappeared, while long-tern talks and compromises are endless and have often a symbolic character. As a result, recent global order represents open and overt 
struggle of numerous macro and micro-agents under conditions of growing resource consumption, economic and political instability, climate fluctuations and confrontation between the transnationals and the nation-states. The role of the UN and other international organizations is slowing down. On the contrary, the role of mobile troops, private armies and subversive activity is rising. The further the more the existing social order is far behind of current transformations of global geopolitical situation. Speaking globally, quite a few resolutions adopted by any international organizations have been fully implemented. It means that international organizations exist for permanent production of papers but not for actual assistance in resolving current conflicts.

Table3. Changes in global order

\begin{tabular}{|c|c|c|}
\hline & 1960-1980s & 2000 and onwards \\
\hline Value basis & Liberalism with a left turn & Technocracy with a right turn \\
\hline Global order forces & Bi-polar balance & Struggle within multi-polar world \\
\hline $\begin{array}{l}\text { Factors of its shaping and } \\
\text { maintenance }\end{array}$ & $\begin{array}{l}\text { International organizations and } \\
\text { talks }\end{array}$ & $\begin{array}{l}\text { Colored revolutions, information attacks } \\
\text { and hybrid wars }\end{array}$ \\
\hline Instruments of maintenance & $\begin{array}{l}\text { Talks, compromises, peace } \\
\text { movement }\end{array}$ & $\begin{array}{l}\text { No such actual instruments except } \\
\text { threats and military actions }\end{array}$ \\
\hline $\begin{array}{l}\text { Role of the UN and other } \\
\text { international institutions }\end{array}$ & Substantial but not decisive & $\begin{array}{l}\text { Role of the UN is going down, role of } \\
\text { financial institutions is growing }\end{array}$ \\
\hline Means of communication & Talks and agreements & Permanent bargaining \\
\hline $\begin{array}{l}\text { Role of civil society } \\
\text { organizations }\end{array}$ & Growing but not decisive & Reducing and depending on mass-media \\
\hline
\end{tabular}

\section{Changes in Institutional Structure of Global Community}

In the first period under consideration an establishment of global peace and safety was considered as underpinnings of institutional structure of global community while in the second one the above goals have become relative. A geopolitical domination of a few global stakeholders came to the forefront. Accordingly, while in the former period a particular nation-states' maintenance and development have been considered as main tasks, in the latter period unlimited expansion of transnational global stakeholders took over. Their struggle generates an overall instability and unpredictability of institutional structure of a global whole. Besides, there is a principled structural difference in the means of maintenance of institutional structure between the first and second periods. In the first one it was territorial principle while in the second one - network structures of various scale and kinds. Actually, it has been a qualitatively new type of institutional structure of global community base on a principle of competition between territorially-based and network-based institutional organizations. In turn, it means that the rules of games are generating now not only 'top-down' but 'bottom-top', and not only by leading global stakeholders but numerous local and very mobile agents. As a result, a fragile balance of national and international interests has been violated. This shift may be considered as the establishment of ad hoc principle of functioning of institutional structure under consideration. This principle paves the way to numerous political and social conflicts. An overall global institutional structure has become uncertain, less controlled and therefore more risky than ever.

Table4. Shifts in relations between transnationals and nation-states

\begin{tabular}{|c|c|c|}
\hline & 1960-1980s & 2000 and onwards \\
\hline Ultimate goals & Peace and safety as basic values & Safety as a relative value \\
\hline Current aims & $\begin{array}{l}\text { Nation-state maintenance and } \\
\text { development }\end{array}$ & $\begin{array}{l}\text { Global expansion and geopolitical } \\
\text { domination }\end{array}$ \\
\hline Value base & $\begin{array}{l}\text { Protection of national unity, safety and } \\
\text { diversity }\end{array}$ & $\begin{array}{l}\text { Unlimited and forced expansion of } \\
\text { cosmopolitan values }\end{array}$ \\
\hline Structural base & $\begin{array}{l}\text { Balance of international and domestic } \\
\text { interests }\end{array}$ & Global transnationals networks prevail \\
\hline Type of global order & Legitimate and peaceful & Voluntary established by force \\
\hline Means of its legitimation & Agreements between two superpowers & $\begin{array}{l}\text { Variety of competing principles of } \\
\text { legitimation }\end{array}$ \\
\hline $\begin{array}{l}\text { Risks generated by their } \\
\text { competition }\end{array}$ & More or less controlled & $\begin{array}{l}\text { Uncontrolled generated by network- } \\
\text { structured global agents }\end{array}$ \\
\hline
\end{tabular}

\section{SHIFTS In MAN-NATURE RELATIONSHIPS}

For years, the 'man-nature' dichotomy has been a guiding methodological principle in social and natural sciences. The humanity activity has been considered as a driving force of these relationships. 
Nowadays, this dichotomy has become obsolescent because the world has rapidly turned into a sociobiotechnical system. This means that the aim of movement toward more ecological and safe world has been replaced by two adversarial aims, that is, intensive resource extraction and the reducing of world population. For the same reason, it became clear that any 'sustainable development' may be reached by thrifty use of natural resources and biodiversity protection. The principles of global environmental politics came to the forefront what in turn began to stimulate the processes of rapprochement and even merging of social and natural sciences, on the one hand, and gives an impetus for the development of new rules of games, on the other. It is indicative that these impetuses came from global civil coalitions like the Taiga rescue network and Rivers without borders (Shvartz and Simonov 2015). Accordingly, the role of the Biosphere including climatic fluctuations in human life and social development should be reconsidered. But the existing mode of production and social reproduction came in conflict with the laws of the Biosphere functioning. That is why numerous international summits, talks and agreements gave very modest results, mainly of symbolic character. Global stakeholders oppose to independent expertize made by multitude interest groups and politically-engaged experts. Appetites of rapidly growing global market are incompatible with evolutionary-shaped laws of the Biosphere functioning. The fact that the majority of impoverished population of the globe will survive at the expense of intensive exploitation of natural resources is not taken into account by such pocket experts.

Table5. Shifts in 'man-nature' relationships

\begin{tabular}{|l|l|l|}
\hline & $1960-1980$ s & 2000 and onwards \\
\hline $\begin{array}{l}\text { Driving force } \\
\text { Targets }\end{array}$ & $\begin{array}{l}\text { Humanity activity } \\
\text { Movement towards more } \\
\text { 'ecological' and safe world } \\
\text { Sustainable development }\end{array}$ & $\begin{array}{l}\text { Sociobiotechnical system activity } \\
\text { Economy of resources and reducing of } \\
\text { world population } \\
\text { Struggle against global warming and for } \\
\text { biodiversity protection } \\
\text { Restricted by the media } \\
\text { Rapidly growing }\end{array}$ \\
$\begin{array}{l}\text { Role of sciences } \\
\text { development }\end{array}$ & $\begin{array}{l}\text { Decisive } \\
\text { Instruments of reconciling } \\
\text { of man-nature antagonism }\end{array}$ & $\begin{array}{l}\text { Talks without any results } \\
\text { (Kyoto protocol) }\end{array}$ \\
\hline
\end{tabular}

\section{DYNAMICS OF CIVIL Society ORganizationS}

Nationally-based grassroots and social movements are now evolving in various directions. The one is an attempt to establish global civil society. The second is to organize ad hoc platforms, forums, etc. for active participation in resolving urgent problems like natural and man-made disasters, rescue operations and render assistance to affected people. The third is attempts to transform protest movements into political parties to reduce inequality and injustice. But at the same time these organizations are used as social base for shaping the counter-movements, for the exerting impact on global public opinion and as a mean for mobilization of 'independent' troops and private armies. The activity of these pro et contra organizations and networks plays a growing role in global and national political life. The type of science-civil society relationships has changed as well. Initially, top-down enlightenment and education have dominated. But now due to various reasons - the growth of a corps of well-educated civil activists, emergence of scientists turned such activists and limited resources of research projects - the situation turned upside down. The researchers are more and more dependent in the assistance of civil activists in such enterprises as crowd-sourcing, crowd-funding, crowd-testing of new medicine, struggle against epidemic diseases, etc. During the 50 years under consideration the relationships between civil organization and power structures varies from collaborative to adversarial. In the recent decade, for the reason of mass influx of migrants into the US and the EU from Africa, Middle East and Latin America an issue of relationships between Anglo-Saxon and other cultures and mode of civil actions and organization remains open.

Table6. Dynamics of civil society organizations

\begin{tabular}{|c|c|c|}
\hline & $1960-1980 \mathrm{~s}$ & 2000 and onwards \\
\hline General trend & $\begin{array}{l}\text { Growth of national social movements } \\
\text { and grassroots }\end{array}$ & $\begin{array}{l}\text { Shaping of network-structured civil } \\
\text { society }\end{array}$ \\
\hline Main aims & Reducing of inequality and injustice & Reducing of inequality and injustice \\
\hline Structural basement & Territorially-based organizations & Network-based structures \\
\hline Means of realization & Struggle for civil rights, national- & Peaceful and armed struggle for human \\
\hline
\end{tabular}




\begin{tabular}{|l|l|l|}
\hline \hline & liberation movements & rights and freedoms \\
Role of IC-networks & Low and territorially-localized & High and globally embracing \\
Significance of science & Top-down enlightenment and & Bottom-top participation in the state \\
and education & education & and foreign affairs \\
The relationships with & Various: from collaborative to & They participate in decision-making \\
power structures & adversarial & related to global issues \\
\hline
\end{tabular}

\section{RELATIONSHIPS BETWEEN LABOR, EDUCATION AND SERVICE ACTIVITY}

Being provoked by the shift from the Second to Fourth technological revolution, the changes in these relationships exert impact on all spheres of natural and social life. First, it was the changes in basic values. In the former period the labor has been considered as a necessity and moral norm while in the latter period - as a mean for gaining personal career, success and wellbeing. Second, in 1960-80s, basing on K. Marx idea of division between work time and leisure time a set in international research projects had been carried out aimed at making a model of optimal day-time structure of various groups of workers and householders. As this project leaders supposed that research allowed to develop a set of norms of social politics. Third, from the early 2000s onwards one could observe a mutual interdependence and integration between various kinds of human activity. As it turned out, modern mobile man by the use of the IC-communication was capable to combine and to fulfill a set of activities simultaneously irrespectively of their spatial location. Fourth, it turned out that the man has to combine his/her routine work with permanent education. In other words, the education turned into a permanent work. That is, the education is not constant social capital but a stock that should be permanently replenished. Finally, the shift from the Second to the Fourth industrial revolution signified qualitative changes in the forms of early socialization stressing a grooving role of virtual environment (Büchler-Neiderberger 2010). Thus, if earlier the city has been one of the substantial means of socialization now its environment has turned into a kind of a 'transit zone.'

Table7. Relationships between labor, education and service structures

\begin{tabular}{|l|l|l|}
\hline & 1960-1980s. & 2000 and onwards \\
\hline Value base & $\begin{array}{l}\text { Labor as necessity and moral } \\
\text { norm } \\
\text { Structural basis }\end{array}$ & Personal success and wellbeing \\
& Mutferentiation & $\begin{array}{l}\text { Mual interdependence and } \\
\text { integration }\end{array}$ \\
Mobility between them & Low and average & Mutual interpenetration \\
Role of IC-sphere & Subaltern & All-embracing and prestigious \\
Education & Constant capital & All-embracing and developing \\
Life codification & Modest & 'Transit' zone \\
Urban environment & Mean of socialization & \\
\hline
\end{tabular}

\section{Changing ROLE OF INFORMATION-COMMUNICATION SPHERE}

Recently a man lives simultaneously in two spheres, material and virtual ones. Global informational environment is governed by mighty national and transnational groups of interest by means of 'two keys', i.e. by switching and reprogramming of information channels (Arsenalt and Castells 2008). The role of this sphere is very important for the reason of its all-embracing character (Castells 1996, 2000; Schwab 2016) and virtualization of our life (Chadwick and Howard 2009). Recently, we are witnessing the emergence of virtual private networks (the VPN system) which are rapidly multiplied. It signifies a new round of competition and struggle between private and common interests (Conti et al. 2013; Jaham et al. 2017).

I put the VPN communication systems here because it tightly interconnected with the following point of the analysis, the issue of changing role of individual and personality in information age. Let us return to the beginning of this text. Of course, from ancient times people used various kinds of information and communication. But only recently the IC-sphere has become a leading mode of public production and consumption ranging from gadgets production till a mean for taming of global economic and political processes. And their structural basement is very diverse as well. It embraces all possible means of communication from press, television, phones and social networks till highways, railroads and aero-cosmic communications. As it has been shown, in post-modern society all these forms are not congruent. On the contrary, they are competing with each other producing knots of international conflicts (The Global Risk... 2016). We are moving towards total digitalization of human communication and shaping a 'collage' perception of reality. National cultures are shrinking and transforming into 'ethnographical pictures' of the past. Previously existed division between labor, 
education and rest time is eliminating, jobless people are migrating over the world. A primary ecostructure (family, parents, neighbors) replaced by virtual contacts in social networks. And the most important: all-embracing digitalization rapidly annihilates any form of verbal text as a main carrier of senses.

That is, as any other technological innovation the creation of global IC-sphere is Janus like. On the one hand, it opens unprecedented opportunities for all forms of human activity. On the other hand, the use of the IC-technologies generates potentially all-embracing risks ranging from total brain washing to a self-destruction of global human community. The risk of this challenge is rather clear: up to now the life of this community has been maintained by the milliards of evolutionary tuned interdependent neuron networks, biochemical, biosocial, technological and so on. Recently, such tuning is implemented either by the politicians or by artificial intellects of various kinds. But nobody knows how the commands generated by a particular artificial intellect will interrelated with the dynamics of the global SBT-system. To my mind, this is a key challenge to humanity and first of all to the global politics, scientific communities and media designers.

Table8. Development of information-communication (IC) sphere

\begin{tabular}{|l|l|l|}
\hline & $1960-1980$ s & 2000 and onwards \\
\hline Main aim & Technical service of public & Leading sphere of public production \\
& production and consumption & and consumption \\
Main functions & Information and propaganda & Governing of global process \\
Structural basis & Press, TV and broadcasting & All-embracing network structure \\
Localization & Mainly territorial & Mainly virtual \\
Impact on power & Mean of their strengthening and & A decisive element of power structures \\
structures & legitimation & used for global government \\
Impact on man's behavior & Various because it combined with & $\begin{array}{l}\text { Decisive used by global and national } \\
\text { stakeholders for structuring of man's } \\
\text { behavior }\end{array}$ \\
& other instruments & \\
\hline
\end{tabular}

\section{JOURNALISM AND MASS-MEDIA}

From the emergence of newspapers and other printed matters they played an important social and cultural role. They fulfilled a great number of functions: the information, communication, enlightenment and education and many others. It is interesting to note that some of the Fathers of Chicago School of Human ecology of the 1920s had initially been the muckrakers, that is, criminal reporters who got information in situ and from the first hands. Many outstanding novels had initially appeared as a set of chapters in the newspapers and journals. Besides, many journalists and reporters took part in various social movements (national-liberation, human rights, environmental, etc.). One of the very important functions of newspapers and broadcasting had been the adaptation of migrants and other newcomers to urban way of life. It would not be an exaggeration to say that during the first period the above means of communication played a role of melting pot assisting to shape a national identity. In sum, they have been a power.

During the second period under consideration the situation has changed qualitatively. The information, education and other abovementioned functions have remained but the functions of the journalism and mass-media as the instruments of shaping an individual and public consciousness came to the forefront. More than that, modern media are relying upon information produced by politically-engaged international civil organizations that began to construct (to dramatize) the news. A growing volume of the fake news has exerted an impact on global politics. That is, the process of a replacement of actual news by dramatized ones has begun. As it has been mentioned in previous paragraph, the media turned in the field of struggle between public and secret IC-powers. An establishment of the VPNs (the Messenger, the Telegram) had been a reaction to the creation of dramatized reality by modern media.

Table9. Changing role of media and journalism

\begin{tabular}{|l|l|l|}
\hline & $1960-1980$ s & 2000 and onwards \\
\hline Main aim & Information & News making and constructing \\
Main functions & $\begin{array}{l}\text { Information \& enlightenment for } \\
\text { shaping national identity }\end{array}$ & $\begin{array}{l}\text { Governing of global process by all means } \\
\text { including Twitter \& Facebook }\end{array}$ \\
Structural basis & Information gained in situ & Politically-constructed news \\
Localization & Local and nation-wide & A decisive element of efficiency of power \\
Impact on power & Their strengthening and & A
\end{tabular}




\begin{tabular}{|l|l|l|}
\hline \hline structures & legitimation & structures \\
Impact on man's & Information, organization and & Mainly manipulating by means of \\
behavior & mobilization & dramatizing of a social reality \\
\hline
\end{tabular}

\section{Technological Shift AND Personality}

During 1960-80s the Western and Russian social theorists saw an issue of personality development as a very acute. The notions of individual social capital, individual life project and a personal life story have emerged. They reflect the raise of a personality's significance in modern society dynamics. The development of civil society, the forms of its participation in the deeds of a state and grassroots activism have been in the focus of attention of social sciences. An important notion of 'expert-citizen' capable to participate directly in decision-making has emerged (Fisher 2003). Privacy as a social norm and scientific notion (a cocoon of basic trust, using the A. Giddens formula) has been considered as the underpinnings of Western democracy (Friedwald and Pohoryles 2013). My own research in that time period and later confirmed this viewpoint (Yanitsky 1988, 2012).

The Fourth technological revolution coupled with growing consumerism provoked a cardinal shift from Homo Faber к Homo Mobile and then to Homo Virtual. A necessity to be permanently included into the 'big virtual world' means a sharp decline of the importance of any form of local life. To be the 'modern' means now to be included into a digital global world (Robinson 2007). Besides, the issue of a 'personality-machine', that is a relationships between human and artificial intellect have become extremely acute. Nowadays, the US and China investments in the R\&D of artificial intellect are estimated no less than tens billions of dollars every year.

Technologically-based media give impetus to a new wave of consumerism which separates individuals and estranges them from each other. Modern social and political technologies dictate to individuals to be included in consumer society even when he/she has a possibility to be isolated from media pressure. By and large, the individuals are not capable to exist without mass-media and social networks. Permanent inclusion in them has become a mode of living. It, in turn, leads to a loss of a critical relation to and estimation of global-and-local life. In particular, such individual is incapable to discuss such complex phenomena as the SBT-systems dynamics and global warming. Uncontrolled use of social networks raises the threat of hackers' attacks and even more penetration of unknown subjects into privacy space. Coupled together, it means that a global informational flow masks the differences between goods and bads, good intensions and criminal design, etc. Relying on the analysis of the above substantial shifts Z. Bauman, U. Beck and J. Urry suggested the concept of a cosmopolitan individual (Bauman 2011; Beck, 2015; Urry, 2008). Bu to my mind, the union of the technocratic ideology and media is the source of permanents risks.

Table10. Personality under technological transition

\begin{tabular}{|l|l|l|}
\hline & 1960-1980s & 2000 and onwards \\
\hline An ultimate goal & Personality development & Consumption growth \\
Value basis & Personality is a main capital of a & Consumption-oriented individual \\
& society (Homo Faber) & (Homo Virtual) \\
Structural basis & Long-term life project with a road & Life project is a function of global \\
& map & SBT-system \\
Means of self-realization & Relatively free choice & Choice governed by media \\
Localization & Local-global & Mainly global \\
Role of IC-technologies & Service & All-embracing \\
Inclusion-exclusion balance & Self-regulated & Governed by mass-media \\
Way of life & Mainly self-regulated & Mainly governed by global media \\
\hline
\end{tabular}

\section{ConClusions}

The Fourth industrial revolution is transforming all spheres of a global whole. The world is becoming more and more transparent and interdependent. The constructor of this shift is a developing capitalist mode of production aimed at economic and geopolitical domination. Orientation on post-material values is replaced by consumerism. Ideology of limits of growth has been replaced by tough struggle for natural resources.

The IC-networks, financial and resource flows, mass migration and international conflicts are the structural basement of growing interdependence of the nation-states, their alliances and local communities. A competition between the transnationals and the nation-states is continuing. Civil 
society institutions are more and more subjected to the interests of nation-states and transnationals. After the decay of bi-polar balance of the global order it has become unstable and hard to predict. A dynamics of international and national institutions is far behind of current global challenges and transformations. Global social and political institutions are transformed into a permanently changing network-flow structure. The megalopolises are losing their role of melting pots turning into international centers of financial activity for some and 'transit zones' for others.

Long-term hopes for gaining the sustainability of global social order are forced out by its allembracing instability and unpredictability. These phenomena are conditioned by global struggle for natural and social resources accompanied by the destruction of national and local social orders and emanation of giant masses of energy of decay. Accordingly, a new subject matter has emerged. A focus of scientific interest is shifted from the studies of linear dynamics of particular subsystems to the analysis of the development of nonlinear dynamics of global SBT-system governed by global media.

Every change in a particular sphere of human activity has its immediate or delayed feedback. Say, a rapid growth of the GNP depends on the existence of cheap labor force at global labor market. By and large, the GNP growth stimulates the rise of living standards and therefore a labor force has becoming more expensive. This process slows down the GNP growth. It is a case of vicious circle. Theoretically, it means that any growth has now its limits. Environmental or man-made catastrophes cannot be considered as an instrument of expanding these limits. On the contrary, such catastrophes have dual negative effect. On the one hand, they raise the cost of immediate rescue operations and further rehabilitation processes. On the other hand, such disasters transforming living areas into dead ones reduce an overall sustainability of the global SBT-system. Of course, these limits may be expanded by various means: by reducing of population growth, introduction of modest living standards, energy economy or by partial resettlement of the earth population on other planets. But all this may have a short-term effect only. The emergence of virtual society generated by the Fourth industrial revolution is Janus like because it simultaneously provides both the unique opportunities for human activity and deadly global threats. One of such threats is a capability of media to 'dramatize', i.e. to socially construct both public consciousness and individual's opinions.

Finally, the research instruments of further global dynamics have to be developed at least in two ways. The one is a decisive turn to problem-oriented and interdisciplinary researches. The naturalists, sociologists, political scientists, physicians, urban planners, environmentalists, etc. should not only to understand each other but to learn to work hand in hand. The second is a necessity to co-ordinate the tempo-rhythm of scientific researches with the ongoing tempo-rhythms of changes generated by the SBT-dynamics, with all its twists and bifurcations. An understanding of the 'world of time changes' is as important as the comprehension of all other transformations within and beyond of global SBTsystem. I am not sure that dominating rationalism and technocratic mode of thinking are the best medicine for better understanding of current and foreseeable transformations.

\section{REFERENCES}

[1] Arsenault A. and Castells M. (2008) Switching Power: Rupert Murdoch and the Global Business of Media Politics. International Sociology 23 (4): 488-513.

[2] Bauman Z. (2011) 44 Letters from Liquid Modern World. Cambridge: Polity Press.

[3] Beck U. (1999) World Risk Society. Malden, MA: Polity Press.

[4] Beck U. (2007) Cosmopolitan Version. Cambridge: Polity Press.

[5] Beck U. (2010) World at Risk. Cambridge: Polity Press.

[6] Beck U. (2015) Emancipatory Catastrophism: What does it mean to Climate Change and Risk Society? Current Sociology, 63 (1): 75-88.

[7] Brundtland, G. and Khalid, M., eds. (1987) Our Common Future. The World Commission on Environment and Development. Oxford, N.Y: Oxford University Press.

[8] Büchler-Neiderberger D. (2010). Childhood Sociology - Defining the State of Arts and Ensuring Reflection. Current Sociology, 58 (2): 155-163.

[9] Castells M. (1996) The Information Age. Economy, Society and Culture. Oxford: Blackwell Publishers, Ltd. 
[10] Castells M. (2000) Materials for an Exploratory Theory of the Network Society. British Journal of Sociology, 51 (1), Jan/March: 5-24.

[11] Chadwick A. and Howard P., eds. (2009) Handbook of Internet Politics. London: Taylor \& Francis.

[12] Frank B., Delano D. and Caniglia B. (2017) Urban Systems: A Socio-Ecological System Perspective. Sociology International Journal. DOI: 10.1546/sij.2017.01.00001

[13] Conti M., Hasani A., Crispo B. (2013) Virtual Private Social Networks and a Facebook Implementation. ACM Transactions on the Web 7 (3): 1-31. Available at: http://www.researchgate.net/publication/262315940_Virtual_private_social_networks_and_a_Fa cebook_implementation

[14] Friedwald M. and Pohoryles J. (2013) Technology and Privacy. Innovation: The European Journal of Social Science Research, 26 (1-2): 1-6.

[15] Giddens, A. (1992) The Consequences of Modernity. Stanford, CA: Stanford University Press.

[16] Giddens A. (2009) The Politics of Climate Change. Cambridge: Polity Press.

[17] Guimarães R. (1991). Bureaucracy and Eco-politics in the Third World. International Sociology 6 (1): 73-96.

[18] Jaham S., Rahman S., Saha S. (2017) Specific Tunneling Protocol Selection for Virtual Private Networks. Paper presented at International conference on Networking Systems and Security. Dhaka, Bangladesh. Available at: http://www.researchgate.net/publication/312190925_ Specific_tunneling_protocol_selection_for_virtual_private_networks

[19] Meadows D.L. and Meadows D. H., eds. (1973) Toward Global Equilibrium. Cambridge, Mass.: Wright-Allen Press.

[20] Meadows D.H., Meadows D. L., Randers J.W. (1989) The Limits to Growth. A Report for the Club of Rome's Project on the Predicament of Mankind. 2nd ed. N.Y.: Universe Books.

[21] Myrdal G. (1968) Asian Drama. An Inquiry into the Poverty of Nations. N.Y: Harvard Univ. Press.

[22] Robinson L. (2007) The Cyberself: The Self-ing Project Goes Online, Symbolic Interaction in the Digital Age, New Media and Society 9 (1): 93-110.

[23] Rozzak T. (1973) Where the Wasteland Ends: Politics and Transcendence in Post-Industrial Society. New York: Doubleday.

[24] Sassen S. (2002) Towards Sociology of Information Technology. Current Sociology, 50 (3): 365-388.

[25] Shvarts E. and Simonov E. (2015) From Environmental Threats to New Rules and Development mechanisms in Eurasia. Available at: https://www.researchgate.net/publication/318570451_ From_environmental_threats_to_new_rules_and_development_in_Eurasia/

[26] Schwab K. (2016) The Fourth Industrial Revolution. Geneva: World Economic Forum.

[27] Toffler A. (1970) Future Shock. New York: Bantam Books.

[28] The Global Risks Report (2016) Geneva: World Economic Forum. Available at: www. weforum.org/risks

[29] Touraine A., Dubet F., Hegedus Z., Wieviorka M. (1983) Anti-nuclear Protest. The Opposition to Nuclear Energy in France. Cambridge: Cambridge University Press.

[30] Urry J. (2008) Mobilities. Cambridge: Polity Press.

[31] Urry J. (2011) Climate Change and Society. Cambridge: Polity Press.

[32] Yanitsky O. (1988) Towards Creating a Socio-Ecological Conception of a City, in Cities and Ecology. Moscow: Centre of International Projects, pp. 54-57.

[33] Yanitsky O. (2012) A Primary Eco-Structure: The Concept and its Testing. Social Analysis, Vo.2 No 2, pp. 7-24.

[34] Yanitsky O. (2016) Socio-bio-technical systems: A New Approach to Man-Nature Interactions, pp. 123-136, in: On Globalization and its Environmental Consequences. The Yanitsky Reader II. Available at: http://www.isras.ru/index.php?page_id1198\&=4603 